\title{
PERUBAHAN VOKAL TINGGI DI AKHIR KATA DALAM DIALEK TAIPING DALAM KALANGAN PELAJAR: ANALISIS FONOLOGI GENERATIF
}

\author{
Noor Syamshida MASA ${ }^{1}$ \\ Nur Farahkhanna MOHD RUSLI*2 \\ Nur Faaizah MD ADAM ${ }^{3}$ \\ 1,2,3 Jabatan Bahasa dan Kesusasteraan Melayu, Fakulti Bahasa dan Komunikasi, \\ Universiti Pendidikan Sultan Idris, Perak \\ 1shida96.ns@gmail.com \\ 2farahkhanna@fbk.upsi.edu.my \\ ${ }^{3}$ nurfaaizah@fbk.upsi.edu.my
}

Manuscript received 19 February 2020

Manuscript accepted 8 June 2020

*Corresponding author

https://doi.org/10.33736/ils.2352.2020

\begin{abstract}
Abstrak
Makalah ini bertujuan untuk menjelaskan perubahan vokal tinggi di akhir kata dalam kalangan pelajar dalam dialek Taiping berdasarkan teori fonologi generatif (Chomsky \& Halle, 1968). Data kajian diperolehi melalui pemerhatian dan temu bual dengan bantuan alat perakam, Ujian Sebutan Lisan dan buku catatan. Informan yang dipilih dalam kajian ini merupakan 20 orang pelajar berbangsa Melayu yang tinggal di Taiping, Perak. Lokasi kajian pula adalah di Sekolah Menengah Kebangsaan Simpang, Perak. Hasil kajian menunjukkan bahawa perkataan yang mempunyai vokal tinggi /i/ dan /u/ di akhir kata akan direalisasikan sebagai [e] dan [o] seperti /bilik/ $\rightarrow$ [bile?], /tantik/ $\rightarrow$ [tante?], /datuk/ $\rightarrow$ [dato?], /kukuh/ $\rightarrow$ [kukoh] dan sebagainya. Berdasarkan data ini, perubahan bunyi vokal tinggi yang berlaku menunjukkan bahawa vokal tinggi /i/ dan /u/ kehilangan fitur [+tinggi] dan akan direalisasikan sebagai vokal separuh tinggi [e] dan [o] melalui pelaksanaan rumus perendahan vokal di lingkungan suku kata akhir tertutup. Data ini kemudiannya dianalisis menggunakan teori fonologi generatif menggunakan rumus fitur distingtif. Hasil kajian menunjukkan bahawa vokal tinggi/i/ dan / $\mathrm{u} /$ mempunyai ciri pembeza yang berlainan antara satu sama lain. Vokal tinggi /i/ mempunyai fitur [-belakang], [+depan] manakala vokal /u/ mempunyai fitur [+belakang], [-depan]. Berdasarkan rumus fitur distingtif Zaharani Ahmad (1993), rumus tersebut telah dikembangkan untuk menentukan fitur vokal separuh tinggi [e] dan [o] yang mempunyai ciri
\end{abstract}


pembeza masing-masing untuk menerangkan perubahan vokal tinggi di akhir kata dalam dialek Taiping. Kajian ini telah dapat menjelaskan sebab perubahan vokal tinggi di akhir kata dalam dialek Taiping, iaitu disebabkan proses perendahan vokal tinggi di akhir kata.

Kata kunci: dialek Taiping; vokal tinggi; akhir kata; fonologi generatif; perendahan vokal

\title{
High Vowel Changes at the end of Words in Taiping Dialects among Students: A Generative Phonological Theory
}

\begin{abstract}
This article aims to explain the high vowel changes at the end of words among students using the Taiping dialect based on generative phonological theory (Chomsky \& Halle, 1968). The data were obtained through observations, and interviews with the help of recorders, Oral Test and notebooks. Informants were selected among 20 Malay students who live in Taiping, Perak. The study area is located at Sekolah Menengah Kebangsaan Simpang, Perak. The result show that words with high vowel /i/ and / $\mathrm{u} /$ at the end of the word were realised as [e] and [o] as /bilik/ $\rightarrow$ [bile?], /tantik/ $\rightarrow$ [tante?], /datuk/ $\rightarrow$ [dato?], /kukuh/ $\rightarrow$ [kukoh] and etc. Based on this data, the changes in the high vowel sound indicate that the high vowels /i/ and /u/ loss features [+high] and are realised as the high half vowel [e] and [o] through the implementation of the vowel reduction formula in the closed syllable environment. This data were then analysed using generative phonological theory using distinctive features. The results show that the high vowels /i/ and / $u /$ have different distinctive features. The high vowels /i/ have the features [-back], [+front] while the /u/ vowels have [+back], [-front]. According to Zaharani Ahmad's (1993) distinctive features formula has been developed to determine the high half vowel features [e] and [o] that have their distinctive features to describe high vowel changes at the end of the word in the Taiping dialect. The study shows that high vowel changes at the end of words in the Taiping dialect are due to the high vowel lowering process at the end of the word.
\end{abstract}

Keywords: Taiping dialect; high vowel; word final syllable; generative phonology; vowels lowering.

\section{Pendahuluan}

Dialek merupakan kelainan bahasa yang digunakan secara kerap oleh individu tertentu. Penggunaan dialek ditentukan oleh kawasan geografi atau keadaan sosial. Menurut Asmah Omar (1988), dialek merupakan kelainan-kelainan bahasa yang tidak merupakan bahasa standard. Semenanjung Malaysia mempunyai beberapa dialek yang dituturkan oleh penuturnya (Mohamad Shahidan, 2005). Asmah Omar (1978) membahagikan dialek kepada dua iaitu dialek sosial dan dialek kawasan.

Perubahan Vokal Tinggi di Akhir Kata dalam Dialek Taiping dalam Kalangan Pelajar: Analisis Fonologi Generatif 
Dialek sosial merupakan dialek yang ditentukan berdasarkan keadaan sosial sesebuah kumpulan atau individu. Dialek sosial dipengaruhi oleh faktor-faktor seperti sosiobudaya khususnya kelas sosial, jantina, kelompok etnik, rangkaian sosial dan ciri-ciri individu. Dialek kawasan pula merupakan dialek yang dituturkan oleh kumpulan manusia dalam sesuatu kawasan geografi Asmah Omar (1978). Dialek kawasan merupakan dialek yang sering digunakan oleh masyarakat seperti dialek Kelantan, dialek Utara, dialek Perak dan sebagainya. Asmah Omar (1988) telah membahagikan dialek di Semenanjung Malaysia kepada tujuh kumpulan dialek seperti berikut:

1) Dialek yang terletak di Barat Laut yang merangkumi kawasan Perlis, Kedah (termasuklah Pulau Langkawi), Pulau Pinang dan Perak Utara hingga Taiping. Dialek ini lebih umum dikenali sebagai dialek Utara atau dialek Kedah.

2) Dialek Perak yang meliputi kawasan Perak Tengah.

3) Dialek Selatan yang meliputi Perak Selatan, Selangor, Melaka dan Johor.

4) Dialek Kelantan yang meliputi kawasannya ialah negeri Kelantan iaitu di sebelah Timur Laut Semenanjung, dan meliputi juga kawasan-kawasan sempadan Pahang dan Terengganu.

5) Dialek Terengganu yang terletak di bahagian Timur Semenanjung.

6) Dialek Pahang yang terdapat di Negeri Pahang,

7) Dialek Negeri Sembilan yang terdapat di Negeri Sembilan.

Berdasarkan pembahagian tersebut, kajian ini akan memfokuskan dialek pertama, iaitu dialek Taiping. Bagi Asmah Omar (1988), dialek yang dikatakan yang mewakili dialek Perak hanya terdapat dalam negeri Perak sahaja di mana keadaan ini berbeza dengan dialek Kedah yang mengalami penyebaran dialek yang melampaui sempadan negeri. Bahagian-bahagian tertentu yang terdapat di negeri Perak merupakan kawasan penyebaran dialek-dialek lain seperti dialek Patani di daerah Ulu Perak dan Larut-Matang, dialek Kedah di daerah Taiping ke utara dan dialek Selangor di daerah Ipoh ke selatan (Asmah Omar, 1988).

Oleh itu, daerah-daerah yang boleh dikatakan betul-betul mewakili kawasan dialek Perak ialah daerah Parit dan Kuala Kangsar. Kuala Kangsar boleh diambil sebagai contoh kawasan peralihan yang ditandai oleh ciri-ciri dialek Kedah dan juga dialek Perak terutamanya di kawasan yang bersempadan dengan Taiping. Selain itu, terdapat juga dialek Melayu Rawa di kawasan-kawasan tertentu seperti di Gopeng dan Selama (Asmah Omar, 1988).

Dialek pertama iaitu dialek Parit yang dikatakan dialek asli Perak mengalami penyebaran di bandar-bandar utama di daerah berkenaan, iaitu Teluk Intan di Selatan, bandar Parit di Utara, Setiawan dan Lumut di barat. Dialek Parit mempunyai tujuh vokal iaitu i, e, ě, a, u, o dan ǒ. Contoh dialek Parit adalah seperti tampŏ dan rupě. Dialek kedua iaitu sistem pertuturan dari Ipoh ke selatan merupakan dialek Selangor di mana dialek Ipoh tidak termasuk sebagai dialek bagi dialek Perak. Hal ini dapat membuktikan bahawa ciri kesinambungan dialek yang tidak dapat ditentukan oleh sempadan pentadbiran (Asmah Omar, 1988).

Perubahan Vokal Tinggi di Akhir Kata dalam Dialek Taiping dalam Kalangan Pelajar: Analisis Fonologi Generatif 
Dialek yang ketiga ialah dialek Kuala Kangsar. Dialek Kuala Kangsar mempunyai ciri yang lebih kurang sama dengan dialek Parit. Perbezaan ketara yang boleh dilihat antara dialek Parit dengan dialek Kuala Kangsar terletak pada kewujudan vokal /a/ pada akhir kata. Dalam dialek Parit, pewujudannya ialah /e/ sedangkan dalam dialek Kuala Kangsar pewujudannya ialah e-pepet /ə/ (Jadual 1).

Jadual 1

Perbezaan sebutan Dialek Parit dan Dialek Kuala Kangsar

\begin{tabular}{ccc}
\hline Prt & KK & Bahasa Melayu Standard \\
\hline Ape & apə & apa \\
bile & bilə & bila \\
\hline
\end{tabular}

(Sumber: Asmah Omar, 1988)

Dialek Gopeng juga memperlihatkan penyimpangan daripada dialek Parit dalam satu dua ciri sahaja. Pertama, dalam dialek Gopeng terdapat diftong -ay (kapay) di lingkungan akhir kata, sebagai sejajaran baik dalam diftong -ay atau dengan urutan -al dalam bahasa Melayu standard. Dalam dialek Parit dapat dilihat kesejajaran untuk diftong dan urutan tersebut ialah /e/ (Jadual 2).

Jadual 2

Perbezaan sebutan Dialek Parit dan Dialek Gopeng

\begin{tabular}{ccc}
\hline Prt & Gp & Bahasa Melayu Standard \\
\hline təbe & təbay & tebal \\
bante & bantay & bantal \\
\hline
\end{tabular}

(Sumber: Asmah Omar, 1988)

Perbezaan kedua dialek Gopeng dengan Parit adalah urutan -as di akhir kata dalam bahasa Melayu standard dengan -ayh dalam dialek Gopeng, dan bukan -eh seperti yang terdapat dalam dialek Parit (Jadual 3).

Jadual 3

Perbezaan Sebutan Dialek Parit dan Dialek Gopeng

\begin{tabular}{ccc}
\hline Prt & Gp & Bahasa Melayu Standard \\
\hline kipeh & kipayh & kipas \\
bəReh & bəRayh & beras \\
\hline
\end{tabular}

(Sumber: Asmah Omar, 1988)

Perak juga menerima pengaruh dialek luar daripada semenanjung seperti dialek Patani dan dialek Rawa. Dialek Patani dituturkan di kawasan Larut Matang dan dibawa oleh imigran dari Patani. Dialek ini dituturkan oleh masyarakat yang tinggal di Hulu Perak khasnya di Gerik, Klian Intan dan Temenggor. Perbezaan antara dialek Perak dengan dialek Patani dapat dilihat dalam contoh di Jadual 4.

Perubahan Vokal Tinggi di Akhir Kata dalam Dialek Taiping dalam Kalangan Pelajar: Analisis Fonologi Generatif 
Jadual 4

Perbezaan sebutan Dialek Perak dan Dialek Patani Daerah Larut Matang

\begin{tabular}{ccc}
\hline Dialek Perak & Pt (LM) & Bahasa Melayu Standard \\
\hline dalam & dalang & dalam \\
kawan & kawang & kawan \\
konon & kunun & konon \\
ateh & ateh & atas \\
\hline
\end{tabular}

(Sumber: Asmah Omar, 1988)

Menurut Asmah Omar (1988), dialek Rawa dituturkan oleh penutur dari Rawa, Sumatera dan masyarakat yang menetap di beberapa kawasan di Gopeng, Kampar, Tapah, Slim River hingga Tanjong Malim. Dialek ini juga terdapat di daerah Selama, Perak Utara. Pusat penyebaran atau kawasan asal dialek Rawa terletak di Sumatera dan terpisah dari Semenanjung Malaysia oleh lautan. Ciri-ciri persamaan antara dialek Perak dengan dialek Rawa merupakan warisan bersama daripada bahasa Melayu induk. Hal ini diperteguhkan dengan adanya pertembungan terus menerus antara penutur dialek Rawa Perak dengan penutur dialek Perak. Jelas bahawa dialek Rawa di Perak telah menyimpang daripada dialek Rawa di Sumatera. Jadual 5 menjunukkan contoh perbezaan dan persamaan dialek Rawa dan dialek Perak.

Jadual 5

Perbezaan sebutan Dialek Perak dengan Dialek Rawa

\begin{tabular}{ccc}
\hline Dialek Perak & Rw & Bahasa Melayu Standard \\
\hline tiko & tika & tikar \\
goreng & gǒřěng & goreng \\
kape & kapal & kapal \\
pukoy & pukuo & pukul \\
kěděkut & kŏdŏkuiq & kěděkut \\
\hline
\end{tabular}

(Sumber: Asmah Omar,1988)

Harun Mat Piah (1983) pula menyatakan terdapat lima kawasan dialek dalam negeri Perak, iaitu:

1) Kawasan Kerian yang berdialek Pulau Pinang dan Kedah (Utara)

2) Kawasan tengah termasuk Kuala Kangsar, Padang Rengas, Sayong dan Lenggong berdialek Kuala Kangsar (Kuala Kangsar)

3) Kawasan Bota termasuk Parit, Bota dan Kampung Gajah berdialek Parit atau dialek Sungai Perak (Parit)

4) Kawasan Hulu Perak termasuk Gerik, Kelian dan Tanjong Malim berdialek baku (Perak Selatan)

5) Kawasan-kawasan dialek imigran termasuk Jawa, Banjar, Rawa dan Mandailing.

Perubahan Vokal Tinggi di Akhir Kata dalam Dialek Taiping dalam Kalangan Pelajar: Analisis Fonologi Generatif 
Sempadan daerah di Perak ditunjukkan seperti dalam Rajah 1. Dialek Melayu Perak dituturkan di seluruh negeri kecuali di bahagian barat laut Perak iaitu daerah Kerian, Larut, Matang dan Selama dan beberapa bahagian di daerah Manjung termasuk Pulau Pangkor dengan dialek kedah (utara) digunakan secara dominan. Di bahagian timur laut negeri Perak (Hulu Perak) dan beberapa kawasan di daerah Selama dan Kerian, penduduknya banyak menggunakan dialek Melayu KelantanPattani. Hal ini disebabkan faktor seperti sempadan geografi dan asimilasi sejarah.

Seterusnya, di bahagian selatan negeri Perak (Hilir Perak dan Batang Padang), daerah Kampar, Kinta dan beberapa kawasan di daerah Manjung lebih terpengaruh dengan dialek Melayu Selatan Semenanjung seperti dialek Selangor, Melaka dan Johor-Riau serta bahasa-bahasa dari kepulauan Indonesia seperti bahasa Jawa, Banjar, Rawa, Mandailing dan Bugis. Di bahagian Perak Tengah pula seperti di Kuala Kangsar, Sayong dan Bota menggunakan loghat asli Perak. la berbeza dengan loghat tempat lain dan digemari orang ramai apabila ada penutur menuturkan yang menggunakan loghat ini. Namun, kajian ini hanya menumpukan kepada dialek Perak di bahagian Perak Utara iaitu dialek Taiping.

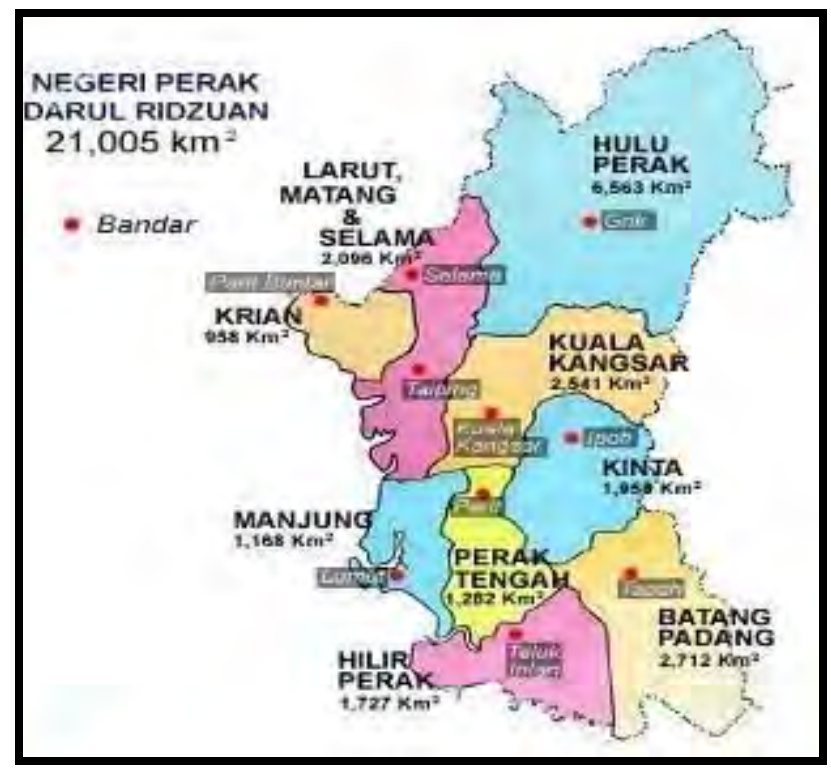

Rajah 1. Peta Daerah Negeri Pera

(Sumber: https://belumoutdoor.files.wordpress.com/2010/02/map_perak.jpg)

\section{Vokal Tinggi /i/ dan / $/$}

Menurut Arbak Othman (1983) dan Abdullah Hassan (2005), vokal bahasa Melayu terdiri daripada enam vokal, iaitu /i, e, a, ə, u, o/. Kedudukan vokal-vokal tersebut boleh dilihat dalam Rajah 2 yang berikut: 


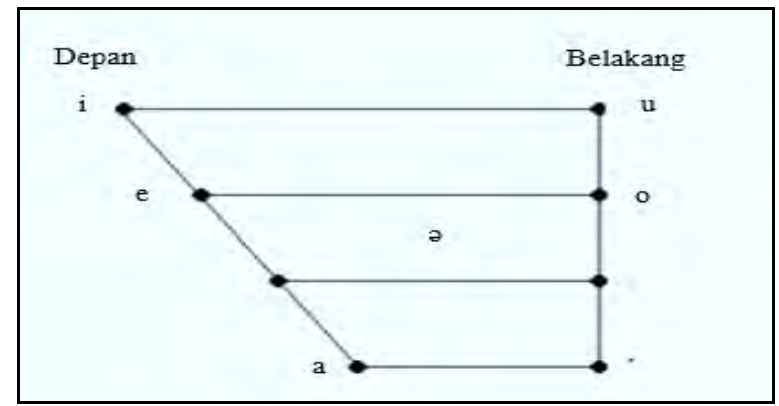

Rajah 2. Kedudukan Vokal Bahasa Melayu

(Sumber: Diubahsuai daripada Abdul Hamid Mahmood, 2017)

Rajah 2 menunjukkan carta inventori vokal Bahasa Melayu. Namun, kajian ini hanya akan menfokuskan vokal depan /i/ dan vokal belakang /u/ yang mengalami perubahan kepada vokal depan /e/ dan vokal belakang /o/ dalam dialek Taiping. Menurut Chaiyanara (2006), vokal /i/ dikenali sebagai vokal tinggi yang dapat disebarkan di posisi awal, tengah dan akhir kata. Vokal/i/ dihasilkan apabila hujung lidah diletakkan pada titik yang paling tinggi di bahagian hadapan mulut. Lelangit lembut akan dirapatkan ke belakang tekak dan menutup rongga hidung. Aliran udara akan keluar melalui rongga mulut sambil menggetarkan pita suara. Semasa melafazkan bunyi vokal /i/, bibir berada dalam keadaan hampar dan kedudukan lidah berada pada kedudukan yang paling tinggi dalam rongga mulut.

Vokal /u/ pula merupakan vokal tinggi yang juga dapat disebarkan pada semua posisi kata. Vokal /u/ dihasilkan dengan menaikkan belakang lidah setinggi mungkin seperti merapati lelangit keras. Walau bagaimanapun, tidak berlaku sekatan udara. Lelangit lembut akan dirapat kepada belakang tekak dan menutup rongga hidung. Aliran udara keluar melalui rongga mulut dan menggetarkan pita suara. Oleh itu semasa melafazkan bunyi ini bibir berada di dalam keadaan bundar (Chaiyanara, 2006). Berdasarkan cara artikulasi ini, maka vokal /i/ dan vokal/u/ dinamakan sebagai vokal tinggi disebabkan kedudukan lidah yang dinaikkan setinggi mungkin semasa proses penghasilan bunyi vokal tersebut.

\section{Sorotan Literatur}

Kajian berkaitan dialek Perak telah banyak dijalankan dan ada kajian berkaitan dialek ini yang telah dianalisis berdasarkan teori fonologi generatif. Hal ini dapat dibuktikan melalui kajian oleh Sakinah Nik Muhammad Naziman dan Fazal Mohamed Sultan (2016) berkaitan kedudukan kata tanya dialek Perak Utara. Kajian tersebut bertujuan mengenal pasti bentuk dan kedudukan kata tanya dalam dialek Perak Utara. Hasil kajian mendapati bahawa bentuk kata tanya dialek Perak Utara mempunyai perbezaan dengan bahasa Melayu standard, namun bentuk ini masih dapat difahami oleh masyarakat lain. Perbezaan yang ketara ialah kata tanya ini mempunyai tiga kedudukan iaitu pada awal, tengah dan akhir ayat.

Kajian yang dijalankan oleh Nor Hashimah Jalaluddin, Norlisafina Sanit, Zaharani Ahmad dan Harishon Mohd Radzi (2016) berkaitan Variasi Kata Ganti Nama Dialek di Pesisir Sungai Perak: Analisis Geographical Informatif System (GIS) pula

Perubahan Vokal Tinggi di Akhir Kata dalam Dialek Taiping dalam Kalangan Pelajar: Analisis Fonologi Generatif 
bertujuan melihat variasi leksikal kata ganti nama diri pertama "saya", kedua "kamu" dan ketiga "mereka" dalam dialek Melayu di pesisir Sungai Perak. Kajian yang melibatkan geo-dialek ini menggabungkan penelitian kebahasaan iaitu dialek dengan maklumat bukan bahasa.

Seterusnya, Siti Noraini Hamzah dan Nor Hashimah Jalaluddin (2018) telah menjalankan kajian berkaitan "Kepelbagaian Varian Leksikal Dialek di Perak: Pendekatan Geographical Information System". Kajian ini merupakan kajian kualitif yang meneliti kepelbagaian dialek yang ada di Perak berdasarkan data leksikal "air", "bantal" dan "saya". Kajian ini hanya meneliti kepelbagaian dialek bagi leksikal "air", "bantal" dan "saya" dalam dialek-dialek di Perak menggunakan pendekatan GIS.

Siti Noraini Hamzah, Nor Hashimah Jalaluddin dan Zaharani Ahmad (2017) juga telah menjalankan kajian yang bertajuk Migrasi Masyarakat Luar dan Pengaruh Dialek di Perak: Analisis Geoliguistik. Bukti data leksikal seperti "air", "saya", "datuk", "nenek", "kamu", "anjing", "betis" dan "mentah". Hasil kajiannya telah dapat memperlihatkan pengaruh daripada dialek Melayu Patani, dialek Banjar, dialek Jawa dan dialek Minang.

Selain itu, kajian-kajian lepas berkaitan teori fonologi generatif telah diteliti seperti kajian yang dijalankan oleh Zaharani Ahmad (1991a) tentang Fonologi Dialek Melayu Perak: Suatu Huraian Atur Rumus. Kajian ini memperlihatkan jenis-jenis rumus fonologi yang berperanan menukarkan bentuk dasar dalam representasi dalaman kepada bentuk fonetik dalam representasi permukaan berdasarkan kerangka teori standard fonologi generatif.

Zaharani Ahmad (1992) juga telah menjalankan kajian bertajuk Rumus Transformasi dalam Fonologi Generatif: Penerapannya pada Bahasa Melayu. Kajian ini bertujuan menghuraikan ciri-ciri asas dan beberapa gagasan penting berkaitan rumus transformasi dalam fonologi dan untuk menerapkan notasi transformasi tersebut untuk menghuraikan beberapa proses fonologi bahasa Melayu.

Zaharani Ahmad (1991b) turut menjalankan kajian bertajuk Masalah Menentukan Representasi dalam Kajian Fonologi. Kajian ini menunjukkan beberapa persoalan teori berhubung dengan proses alternasi morfem dan kaedah menentukan morfem dasar dalam kajian fonologi dialek Melayu Perak. Kerangka teori fonologi generatif mempunyai beberapa ciri umum yang dijadikan landasan untuk menentukan morfem dasar bagi sesuatu yang mengalami proses alternasi, namun masalah teori tetap timbul.

Kajian yang dijalankan oleh Shahidi A. H. dan Rahim Aman (2010) bertajuk Pengaruh Dialek dalam Pertuturan Bahasa Melayu Standard: Pencerakinan Bunyi Berasaskan Spektrogram dapat membantu memahami teori fonologi generatif. Secara keseluruhan, kajian-kajian yang dinyatakan dijadikan sebagai panduan dalam menghasilkan sebuah kajian ilmiah. Selain itu, kajian-kajian ini sedikit sebanyak memberi maklumat yang berguna untuk kajian yang dijalankan. Kajian-kajian yang berkaitan ini juga membantu percambahan idea untuk menjalankan kajian berkaitan dialek Taiping berdasarkan analisis teori fonologi generatif.

Namun, dapat dilihat juga bahawa setiap kajian mempunyai fokus atau objektif yang berbeza-beza antara satu sama lain. Oleh sebab kajian berkenaan dengan pertuturan dialek Taiping yang berada di Perak, khususnya yang dituturkan 
dalam kalangan pelajar amat terhad, maka kajian ini akan mengisi kelompangan tersebut dengan menfokuskan pola perubahan vokal tinggi /i/ dan /u/ di akhir kata.

\section{Metodologi}

Kajian ini merupakan kajian tinjauan yang berbentuk kualitatif. 20 orang responden telah dipilih dalam kalangan pelajar Melayu tingkatan 4 kelas $4 \mathrm{VT} 2$ yang bersekolah di Sekolah Menengah Kebangsaan Simpang, Simpang, Perak dan semuanya menuturkan dialek Taiping. Pemilihan ini bertujuan agar setiap sampel mempunyai kemungkinan yang sama, iaitu menggunakan dialek Taiping semasa bertutur. Seperti yang dijelaskan Nur Farahkhanna Mohd Rusli, Adi Yasran Abdul Aziz, Raja Masittah Raja Ariffin, Mohd Sharifudin Yusop dan Saidatul Faiqah Samasu (2015), pemilihan responden untuk suatu kajian dialek wajar dihadkan dalam kelompok komuniti yang sama bagi mendapatkan ujaran yang asli dan bersifat konvensional tanpa pengaruh daripada bahasa Melayu atau dialek-dialek Melayu yang lain. Selain itu, pemilihan responden dilakukan berdasarkan bilangan keseluruhan pelajar yang berada di kelas tersebut memandangkan pengkaji merupakan guru mata pelajaran bahasa Melayu bagi kelas tersebut. Hal ini secara tidak langsung memudahkan proses pengumpulan data yang bersesuaian dengan objektif kajian dapat diperoleh.

Seterusnya, kajian ini menggunakan kaedah temu bual untuk mendapatkan maklumat dan data daripada responden. Temu bual yang dijalankan berbentuk tertutup, iaitu jawapan responden adalah berdasarkan Ujian Sebutan Lisan. Responden akan menyebut perkataan-perkataan yang telah disediakan. Temu bual tertutup ini telah digunakan untuk mengutip data Ujian Sebutan Lisan responden berdasarkan instrumen kajian yang telah dibina. Hal ini memudahkan proses menganalisis perubahan vokal tinggi di akhir kata dalam dialek Taiping dilakukan.

Selain itu, kaedah pemerhatian turut digunakan untuk mendapatkan data, iaitu melalui keberadaan pengkaji di kawasan kajian. Pengkaji telah pergi ke lapangan iaitu ke Sekolah Menengah Kebangsaan Simpang, Simpang, Perak sendiri untuk melihat sejauh mana penggunaan dialek digunakan semasa sesi pengajaran dan pembelajaran dijalankan. Pemerhatian ini telah dijalankan selama dua bulan, iaitu sepanjang tempoh Latihan Mengajar dilaksanakan. Buku catatan juga digunakan untuk merekod setiap pemerhatian yang dilakukan.

Data yang diperolehi kemudiannya akan ditranskripsikan dalam bentuk fonetik dan fonemik menggunakan Lambang Fonetik Antarabangsa (International Phonetic Alphabet, IPA) untuk melihat perubahan vokal tinggi di akhir kata dalam dialek Taiping. Data seterusnya akan dianalisis dengan menggunakan teori fonologi generatif model linear untuk menjelaskan secara terperinci sebab dan bagaimana perubahan bunyi vokal tinggi berlaku di akhir kata dalam dialek Taiping.

\section{Teori Fonologi Generatif}

Fonologi generatif merupakan satu bidang kajian yang menerapkan ilmu sains dalam analisis bunyi bahasa yang dikembangkan oleh Chomsky dan Halle (1968). Aliran fonologi generatif memperlihatkan dua jenis representasi, iaitu representasi dalaman (representasi fonemik) yang ditranskripsi dengan menggunakan garis

Perubahan Vokal Tinggi di Akhir Kata dalam Dialek Taiping dalam Kalangan Pelajar: Analisis Fonologi Generatif 
miring / /, dan representasi permukaan (representasi fonetik) yang ditranskripsikan dengan menggunakan tanda kurung siku [ ] Chomsky dan Halle (1968) menjelaskan representasi dalaman sebagai bentuk bunyi abstrak yang wujud sebelum lahirnya representasi permukaan. Representasi permukaan pula merupakan bentuk bunyi bahasa atau bunyi bahasa sebenar yang dituturkan oleh manusia.

Menurut Zaharani Ahmad (1993), dalam kerangka teori fonologi generatif, rumus-rumus fonologi memainkan peranan penting untuk menukar representasi dalaman kepada representasi permukaan. Seperti yang dijelaskan oleh Farid M. Onn (1988), tujuan utama analisis fonologi generatif adalah untuk memformalisasi kecekapan intrinsik penutur sebagai satu sistem rumus yang bertanggungjawab melahirkan representasi fonetik daripada struktur permukaan sintaksis. Sehubungan dengan itu, pendekatan fonologi generatif menekankan aplikasi rumus tertentu yang dapat membina rumusan bagi menghasilkan bentuk fonetik yang tepat dan tidak bercanggah dengan sistem bahasa yang dikaji (Adi Yasran Abdul Aziz, Raja Masittah Raja Ariffin, Mohd Sharifudin Yusop dan Nur Farahkhanna Mohd Rusli 2014).

Selain itu, analisis fonologi generatif juga memberi penekanan kepada fitur distingtif. Menurut Schane (1973), analisis generatif menolak fonem sebagai unit asas bunyi bahasa seperti yang diterapkan dalam analisis struktural. Dalam erti kata lain, fonem tidak lagi dianggap sebagai unit nahu terkecil yang membezakan makna seperti yang difahami dalam aliran struktural, sebaliknya digantikan dengan serangkaian fitur distingtif berdasarkan aliran fonologi generatif (Saidatul Faiqah Samasu \& Adi Yasran Abdul Aziz, 2013).

Bagi Roca dan Johnson (1999), fitur distingtif merupakan unit paling asas dalam kajian fonologi. Tambahnya, fitur distingtif merupakan parameter pembeza bunyi yang mempunyai nilai binari atau dedua sama ada nilai positif $(+)$ atau negatif $(-)$. Segmen yang ditandai dengan nilai positif mempunyai ciri-ciri bunyi yang dinyatakan manakala segmen yang ditandai dengan nilai negatif tidak mempunyai ciri-ciri yang dinyatakan.

Oleh yang demikian, dalam kajian ini, formalisasi rumus yang menerapkan analisis struktural dalam menjelaskan proses perubahan vokal tinggi /i/ dan /u/ kepada vokal [e] dan [o] di akhir kata yang telah dibincangkan dalam kajian terdahulu akan diberi penilaian semula dengan menggunakan pendekatan fonologi generatif. Ertinya, rumus-rumus yang diformalisasikan dalam bentuk segmen sebelum ini akan dikembangkan dan dianalisis dengan lebih terperinci dan berpada dengan menggunakan fitur-fitur distingtif yang kini merupakan unit nahu terkecil yang membezakan makna.

\section{Analisis dan Perbincangan}

Analisis tentang perubahan vokal tinggi /i/ dan /u/ di akhir kata telah dijelaskan oleh Zaharani Ahmad (1993) seperti yang diformalisasikan dalam rumus berikut:

1.

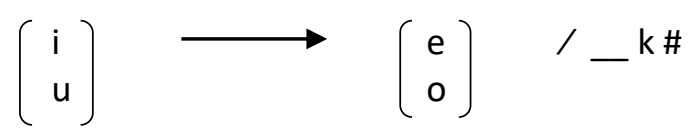

(Sumber: Zaharani Ahmad, 1993)

Perubahan Vokal Tinggi di Akhir Kata dalam Dialek Taiping dalam Kalangan Pelajar: Analisis Fonologi Generatif 
Dalam rumus fonologi generatif, rumus-rumus fonologi bukan sahaja dinyatakan dalam bentuk segmen, tetapi diformalisasikan dalam bentuk fitur distingtif. Oleh itu, fonem tidak lagi dianggap sebagai sebagai unit dasar (basic unit) dan tempatnya diambil alih oleh fitur distingtif. Selain itu, gagasan fitur ini juga penting sebagai satu notasi yang dapat menggabungkan sekumpulan segmen yang berada dalam satu kelas alamiah (natural). Proses fonologi terlaksana ke atas satu kumpulan segmen yang berada dalam satu kelas alamiah (natural) bukannya pada satu segmen secara individidu (Zaharani Ahmad, 1993).

Oleh itu, rumus 1 yang diformalisasikan dalam bentuk segmen tersebut boleh dikembangkan kepada rumus fitur distingtif kerana dalam aliran fonologi generatif, fonem bukan lagi unit terkecil bahasa sebaliknya digantikan dengan fitur distingtif. Berikut merupakan formalisasi fitur secara umum bagi vokal /i/ dan vokal /u/ yang direalisasikan sebagai [e] dan [o] untuk menjelaskan perubahan tersebut:

$$
\text { 2. }\left(\begin{array}{c}
+ \text { silabik } \\
- \text { rendah }
\end{array}\right) \rightarrow\left(\begin{array}{c}
+ \text { silabik } \\
- \text { tinggi }
\end{array}\right) \quad / \ldots[- \text { silabik }] \#
$$

(Sumber: Zaharani Ahmad, 1993)

Seperti yang dijelaskan sebelum ini, rumus perendahan vokal dalam rumus 1 yang diformalisasikan dalam bentuk segmen dapat dikembangkan kepada rumus yang diformalisasikan dalam bentuk fitur distingtif seperti yang dikemukakan dalam rumus 2. Namun, rumus 2 terlalu umum sifatnya untuk menjelaskan perendahan vokal tinggi /i/ dan / $\mathrm{u} /$ secara berpada. Hal ini kerana, rumus tersebut boleh mewakili huruf vokal [e], [o], [a] dan [ə]. Hal ini disebabkan oleh vokal [a] dan [ə] juga termasuk dalam golongan vokal berfitur [-tinggi]. Oleh itu, untuk mengecualikan vokal [a] dan [ə], maka rumus 2 boleh dikembangkan lagi kepada unit yang lebih kecil untuk menunjukkan formalisasi rumus yang melibatkan perubahan vokal tinggi /i/ kepada vokal separuh tinggi [e], dan vokal tinggi / $\mathrm{u} /$ kepada vokal separuh tinggi [o] sahaja.

\section{Perubahan Vokal Tinggi /I/ di Akhir Kata}

Dalam dialek Taiping, rumus segmen berikut dapat menjelaskan proses perendahan vokal /i/ kepada vokal [e]:

$$
\text { 3. } \quad \mathrm{i} \rightarrow \mathrm{e} / \ldots \mathrm{k} \#
$$

Berdasarkan rumus 3, dialek Taiping menunjukkan proses perendahan vokal tinggi /i/ kepada vokal separuh tinggi [e] apabila berada di suku kata akhir tertutup. Proses perendahan ini dapat dilihat dalam contoh-contoh berikut (Jadual 6): 
Jadual 6.

Perubahan Vokal Tinggi ///

\begin{tabular}{ccc}
\hline Ejaan & Fonemik & Fonetik \\
\hline 'betik' & /bətik/ & [bə.te?] \\
'cantik' & /tantik/ & [tan.te?] \\
'dabik' & /dabik/ & [da.be?] \\
'ganjil' & /gandzil/ & [gan.dzel] \\
'menatih' & /mənatih/ & [mã.nã.teh] \\
'selasih' & /səlasih/ & [sə.la.seh] \\
'pelamin' & /pəlamin/ & [pə.la.mẽn] \\
\hline
\end{tabular}

Namun, seperti yang dijelaskan sebelum ini, segmen bukan lagi unit terkecil bahasa sebaliknya unit terkecil bahasa diganti dengan fitur distingtif. Menurut Christiane (1978), golongan Prague School telah memulakan kajian berkaitan fonem secara terperinci. Mereka telah menamakan fonem sebagai satu gugusan fitur distingtif. Fitur distingtif ialah unit paling asas dalam kajian fonologi. Fitur distingtif merupakan parameter pembeza bunyi yang mempunyai nilai dedua sama ada positif $(+)$ atau negatif $(-)$ (Roca \& Johnson, 1999). Konsep fitur distingtif kemudiannya diperkemas oleh Trubetzkoy dan Jakobson dengan memperkenalkan konsep dedua, dan kemudiannya diikuti oleh Chomsky dan Halle dalam The Sound Pattern of English.

Setiap bunyi yang dikenali sebagai fonem mempunyai ciri-ciri atau fitur-fitur yang membezakannya daripada fonem lain. Fitur distingtif juga membolehkan pengkaji membuat perbandingan setiap fonem untuk melihat persamaan dan perbezaan antara satu sama lain. Hal ini penting untuk menunjukkan kualiti bunyibunyi tersebut atau membezakan cara dan daerah sebutan bagi bunyi-bunyi tersebut (Indirawati Zahid \& Mardian Shah Omar, 2006). Menurut Schane dalam Zaharani Ahmad (1992), fungsi fitur distingtif ialah:

1. Fitur dapat memberikan huraian dan fungsi fonetik yang sistematik.

2. Fitur dapat membezakan fungsi fonemik atau membezakan butir leksikal pada peringkat yang lebih abstrak.

3. Fitur dapat mendefinisikan kelas semula jadi, iaitu fonem-fonem tertentu dapat dimasukkan ke dalam satu kumpulan apabila fonem-fonem penggalan tersebut mengalami proses yang sama.

Dalam mengklasifikasikan bunyi vokal, ciri-ciri pembeza seperti tinggi, tengah, rendah, depan, belakang, bundar dan hampar juga perlu digunakan. Contohnya, apabila membandingkan darjah ketinggian vokal atau kedudukan lidah semasa mengujarkan bunyi penggalan, parameter tinggi dan rendah perlu diambil kira. Hal ini dapat ditunjukkan dalam Jadual 7 dan 8.

Perubahan Vokal Tinggi di Akhir Kata dalam Dialek Taiping dalam Kalangan Pelajar: Analisis Fonologi Generatif 
Jadual 7

Darjah Ketinggian Vokal

\begin{tabular}{cccc}
\hline & Vokal Tinggi & Vokal Tengah & Vokal Rendah \\
\hline Tinggi & + & - & - \\
Rendah & - & - & + \\
\hline
\end{tabular}

(Sumber: Indirawati Zahid dan Mardian Shah Omar, 2006)

Selain itu, fitur-fitur fonem vokal tunggal atau monoftong dalam bahasa Melayu dapat dinyatakan dalam matriks fitur distingtif yang berikut (Rajah 3):

Jadual 8

Matriks Fitur Distingtif Vokal Bahasa Melayu (Diubahsuai daripada Paitoon M.

Chaiyanara, 2006)

\begin{tabular}{ccccccc}
\hline & /i/ & /u/ & /e/ & /o/ & /a/ & /ə/ \\
\hline Tinggi & + & + & - & - & - & - \\
Rendah & - & - & - & - & + & - \\
Depan & + & - & + & - & + & - \\
Belakang & - & + & - & + & - & - \\
Bundar & - & + & - & + & - & - \\
ATR & + & + & + & + & - & + \\
\hline
\end{tabular}

Berdasarkan fitur-fitur yang disenaraikan, dapat dikatakan bahawa representasi sesuatu fonem itu dinyatakan sebagai satu kelompok fitur. Dalam menyatakan bunyi-bunyi dengan fitur-fitur pembezanya, tidak semua fitur perlu dijelaskan lagi jika suatu fitur yang lebih penting telah dinyatakan atau disebut (Indirawati Zahid dan Mardian Shah Omar, 2006). Jadi fitur tidak akan bersifat lewah atau berulang-ulang. Menurut Schane (dalam Zaharani Ahmad, 1992), terdapat lima kriteria yang diperlukan untuk memilih fitur-fitur tersebut, iaitu:

a) Sesuatu fitur itu perlulah mempunyai ciri yang berkaitan dengan tiga perkara (Jadual 8).

b) Sesuatu fitur itu perlulah berpada-pada dalam menunjukkan fitur perbezaan fonetik yang ada.

c) Sesuatu fitur itu mestilah dapat disesuaikan dengan prinsip alofon sesuatu bahasa.

d) Sesuatu set fitur itu haruslah boleh disesuaikan dengan semua perbezaan yang perlu dalam sistem tersebut.

e) Sesuatu set fitur itu perlulah boleh mewujudkan kelas semula jadi yang sesuai untuk menyatakan perubahan fonologi yang berlaku.

Perubahan Vokal Tinggi di Akhir Kata dalam Dialek Taiping dalam Kalangan Pelajar: Analisis Fonologi Generatif 
Jadual 9

Fitur dalam Hubungan Fonetik

\begin{tabular}{lc}
\hline Hubungan Fonetik & Fitur \\
\hline Artikulatori & [koronal], [tinggi] \\
Akustik & [sonoran], [striden] \\
Persepsi & {$[$ silabik],[ tekanan] } \\
\hline & (Sumber: Indirawati Zahi
\end{tabular}

Jelaslah bahawa, fitur distingtif dapat menunjukkan secara terperinci tentang ciri-ciri bunyi dalam sesebuah bahasa. Oleh itu, fitur distingtif wajar digunakan kerana ia merupakan unit terkecil nahu yang membezakan makna. Analisis peringkat segmen tidak dapat menggambarkan secara tepat proses fonologi yang berlaku. Penggunaan fitur distingtif agak fleksibel kerana hanya satu atau beberapa jenis fitur sahaja yang digunakan untuk menyatakan kelas alamiah bagi sekumpulan bunyi. Hal ini dapat mengelak daripada berlaku pertindanan fungsi atau kelewahan fitur. Oleh itu, rumus segmen yang diformalisasikan dalam rumus 3 sebelum ini boleh direpresentasikan secara lebih terperinci dengan menggunakan rumus fitur distingtif yang berikut:

4.

$$
\left(\begin{array}{c}
\text { +tinggi } \\
\text {-belakang }
\end{array}\right) \rightarrow\left(\begin{array}{l}
\text {-tinggi } \\
\text {-rendah } \\
\text {-belakang } \\
+ \text { depan } \\
+ \text { ATR }
\end{array}\right) /-k \#
$$

Berdasarkan rumus 4, segmen vokal /i/ boleh diperincikan kepada kepada fitur [+tinggi] dan [-belakang]. Vokal [e] pula boleh diperincikan kepada fitur [-tinggi], [-rendah], [-belakang], [+depan] dan [+ATR]. Oleh itu, berdasarkan rumus 3 iaitu rumus segmen, jelas bahawa ia boleh dikembangkan kepada rumus 4 , iaitu rumus fitur distingtif. Perincian ini jelas menunjukkan bahawa fonem tidak lagi dianggap sebagai unit dasar sebaliknya digantikan dengan fitur distingtif (Zaharani Ahmad, 1993). Menurut Indrawati Zahid dan Mardian Shah Omar (2006), melalui kaedah fitur distingtif, bunyi-bunyi penggalan dapat dipecahkan kepada unit-unit yang lebih kecil, iaitu fitur-fiturnya.

Seperti yang dijelaskan oleh Abdul Latif Zen (2016), fonem tidak dianggap sebagai satuan terkecil dalam analisis fonologi kerana fonem boleh dipecahkan menjadi unit yang lebih kecil yang dikenali sebagai fitur. Fitur-fitur ini digunakan untuk membezakan antara satu fonem dengan fonem yang lain atau untuk melihat perubahan fonem tertentu berubah menjadi fonem lain. Menurut Adi Yasran Abdul Aziz (2012), fitur distingtif (ciri pembeza) merupakan unit terkecil nahu yang membezakan makna. Berdasarkan fitur distingtif, fonem dalam sesuatu bahasa boleh dianalisis atau dipecahkan kepada seberkas fitur. Jelaslah bahawa, fitur distingtif diperlukan dalam analisis fonologi kerana ia ialah unit terkecil nahu yang membezakan makna.

Perubahan Vokal Tinggi di Akhir Kata dalam Dialek Taiping dalam Kalangan Pelajar: Analisis Fonologi Generatif 
Selain itu, rumus 2 seperti yang dinyatakan oleh Zaharani Ahmad (1993) boleh dikembangkan dengan lebih terperinci kepada rumus 4, iaitu rumus fitur distingtif bagi vokal/i/. Hal ini penting untuk menjelaskan fitur bagi vokal/i/ kerana vokal /i/ mempunyai ciri-ciri pembeza yang berlainan dengan vokal / $\mathrm{l} /$ yang juga merupakan vokal tinggi. Berdasarkan rajah 3, dapat dilihat bahawa vokal/i/ berfitur [-belakang] dan [+depan] manakala vokal/u/ berfitur [+belakang] dan [-depan].

Perlu difahami bahawa fitur [-belakang] dan [+depan] bukan sahaja diwakili oleh vokal /i/, sebaliknya turut diwakili oleh vokal /e/ dan /a/. Hal ini kerana fitur [+depan] merujuk kepada vokal depan dan [-belakang] pula bermaksud bukan terdiri daripada vokal belakang. Manakala fitur [+belakang] dan [-depan] bukan hanya boleh diwakili oleh vokal /u/ sebaliknya boleh mewakili /o/. Hal ini kerana, fitur [+belakang] merujuk kepada vokal belakang dan [-depan] pula bermaksud bukan terdiri daripada vokal depan. Oleh sebab itu, pecahan rumus ini penting disebabkan setiap vokal tinggi masing-masing mempunyai fitur yang berbeza.

Dalam rumus 4, fitur [-tinggi], [-rendah], [-belakang], [+depan] dan [+ATR] yang dinyatakan adalah untuk menyatakan ciri bagi vokal [e] sahaja. Fitur [-tinggi] dinyatakan untuk mengecualikan ciri vokal /i/ dan vokal /u/ manakala fitur [-rendah] pula untuk mengecualikan ciri vokal /a/. Kemudian, fitur [-belakang] yang dinyatakan bertujuan mengecualikan ciri vokal / $\mathrm{u} /$ dan vokal /o/ dan fitur [+depan] untuk mengecualikan ciri vokal /u/, /o/ dan / /. Fitur [+ATR] pula untuk mengecualikan vokal /a/. Oleh itu, fitur yang dinyatakan dalam rumus 4 akan dapat merujuk kepada ciri bagi vokal [e] sahaja.

Berdasarkan rumus 4, vokal /i/ yang berfitur [+tinggi] dan [-belakang] telah kehilangan fitur [+tinggi] apabila ujarannya direalisasikan kepada vokal [e] yang mempunyai fitur [-tinggi]. Merujuk rajah 3, ciri yang membezakan vokal /i/ dan /e/ hanyalah fitur [-tinggi]. Menurut Asmah Omar (1995), vokal /i/ dalam kebanyakan dialek tidak dapat menempati lingkungan sebelum konsonan penutup kata kerana di tempatnya terdapat [e]. Vokal [e] dianggap sebagai alofon lingkungan bagi fonem /i/ dalam fonologi sinkronik manakala dalam fonologi diakronik, vokal [e] merupakan refleks dari fonem induk *i. Apabila vokal $*_{i}$ berubah menjadi [e], ciri distingtif vokal $*_{i}$ [+tinggi] akan digantikan dengan ciri distingtif [+rendah] (Asmah Omar, 1995).

Menurut Teoh (1994), rumus perendahan vokal yang pada dasarnya merendahkan vokal [+tinggi] kepada vokal [-tinggi] dalam suku kata terakhir untuk membentuk vokal tengah dalam suku kata kedua. Hal ini boleh dilihat dengan mengandaikan struktur asas perkataan ini mempunyai vokal [+tinggi] iaitu Ki\$̧KiK seperti perkataan /pilih/. Namun berdasarkan rumus, vokal [+tinggi] ini direndahkan kepada vokal [-tinggi] seperti perkataan /pilih/ $\rightarrow$ [pileh]. Berdasarkan struktur Ki\$̦KiK, pada suku kata KiK, vokal /i/ direndahkan kepada [e] (Teoh, 1994). Jelaslah bahawa, analisis segmen sebelum ini boleh dikembangkan dengan lebih terperinci dan berpada, iaitu rumus 2 telah dikembangkan untuk menunjukkan ciri-ciri fitur bagi vokal [e] itu sahaja kerana rumus 2 yang dinyatakan terlalu umum sifatnya.

\section{Perubahan Vokal Tinggi /U/ di Akhir Kata}

Rumus 1 sebelum ini menjelaskan secara umum tentang rumus perendahan vokal tinggi di akhir kata dalam dialek Taiping. Rumus tersebut boleh dipecahkan untuk

Perubahan Vokal Tinggi di Akhir Kata dalam Dialek Taiping dalam Kalangan Pelajar: Analisis Fonologi Generatif 
menjelaskan perendahan vokal tinggi / $\mathrm{u} /$ kepada [o] di akhir kata seperti yang diformalisasikan dalam rumus berikut:

$$
\text { 5. } u \rightarrow o / \ldots k \#
$$

Berdasarkan formalisasi rumus di atas, vokal tinggi / $u$ / di suku kata akhir tertutup dalam dialek Taiping akan direalisasikan menjadi vokal [o]. Proses perendahan ini dapat dilihat dalam contoh-contoh dalam Jadual 9.

Jadual 9.

Perubahan Vokal Tinggi /U/

\begin{tabular}{lll}
\hline Ejaan & Fonemik & Fonetik \\
\hline 'asuh' & /asuh/ & [a.soh] \\
'buruk' & /buruk/ & [bu.ro?] \\
'campur' & /tampur/ & [tam.poq] \\
'gandum' & /gandum/ & [gan.dom] \\
'petunjuk' & /pətundzuk/ & [pə.tun.dzo?] \\
'sepuluh' & /səpuluh/ & [sə.pu.loh] \\
'telur' & /təlur/ & [tə.loq] \\
'tengkujuh' & /təykudzuh/ & [təy.ku.dzoh] \\
\hline
\end{tabular}

Seperti yang dijelaskan sebelum ini, analisis fitur distingtif juga digunakan untuk menunjukkan ciri yang bertentangan dengan menggunakan tanda tambah $(+)$ dan tolak (-). Kedua-dua lambang ini dapat menunjukkan sama ada sesuatu fitur itu dimiliki oleh suatu segmen atau sebaliknya. Contohnya, untuk melabelkan suatu segmen sebagai bunyi bersuara dan tidak bersuara, hanya satu fitur sahaja yang diperlukan iaitu, fitur [bersuara]. Fitur tersebut boleh dispesifikasikan sebagai fitur [+bersuara] untuk segmen bersuara dan [-bersuara] untuk segmen tak bersuara.

Menurut Indirawati Zahid dan Mardian Shah Omar (2006), sistem fitur $p$ distingtif dapat menunjukkan hubungan pasangan bunyi secara tepat dan jelas. Contohnya, fonem /m/ dan /b/ kedua-duanya dihasilkan dengan menggunakan artikulator bibir. Namun, kedua-dua fonem dapat dibezakan dari segi bunyi oral atau nasal melalui fitur distingtif seperti yang ditunjukkan dalam data berikut:

$$
\begin{array}{lll}
/ \mathrm{b} / & \longrightarrow & {[+ \text { oral], [- sengau }]} \\
\mathrm{h} / & \longrightarrow & {[- \text { oral }],[+ \text { sengau }]}
\end{array}
$$

Selain itu, analisis fitur membantu membezakan fitur yang tidak jelas perbezaannya. Contohnya, terdapat fonem vokal yang berbeza dari segi ketinggian lidah manakala bunyi konsonan pula berbeza dari segi daerah artikulasi. Hal ini dapat dijelaskan dengan menggunakan fitur distingtif. Oleh itu, analisis fitur distingtif memainkan peranan penting untuk membezakan dua ciri yang bertentangan. Tambahan pula, analisis fitur juga mewujudkan sebuah sistem yang efektif, teratur dan sistematik untuk mengklasifikasikan bunyi atau fonem menurut

Perubahan Vokal Tinggi di Akhir Kata dalam Dialek Taiping dalam Kalangan Pelajar: Analisis Fonologi Generatif 
fitur-fitur bunyi (Indirawati Zahid \& Mardian Shah Omar, 2006). Oleh sebab itu, perubahan yang berlaku dalam rumus 5 boleh dikembangkan dan direpresentasikan dengan lebih tepat dengan menggunakan rumus fitur distingtif berikut:

6.

$$
\left(\begin{array}{l}
\text { +tinggi } \\
\text { +belakang }
\end{array}\right) \rightarrow\left(\begin{array}{l}
\text {-tinggi } \\
\text {-rendah } \\
+ \text { belakang } \\
\text {-depan } \\
+ \text { ATR }
\end{array}\right) /{ }^{\mathrm{k} \#}
$$

Berdasarkan perbincangan, rumus 5 yang merupakan rumus segmen sebelum ini boleh dikembangkan kepada rumus 6 , iaitu rumus fitur distingtif dengan mengemukakan fitur-fitur seperti fitur [+tinggi] dan [+belakang] bagi vokal / $\mathrm{u} /$, dan fitur [-tinggi], [-rendah], [+belakang], [-depan] dan [+ATR] bagi vokal [o]. Perincian ini jelas menunjukkan bahawa fitur distingtif merupakan elemen terkecil untuk membina sesuatu fonem (Adi Yasran Abdul Aziz, 2012).

Tambahan juga, rumus 2 seperti yang dinyatakan oleh Zaharani Ahmad (1993) boleh dikembangkan dengan lebih terperinci kepada rumus 6 bagi mencirikan vokal /u/. Hal ini penting kerana walaupun vokal / $\mathrm{u} /$ dan vokal /i/ kedua-duanya merupakan vokal tinggi. Namun, kedua-dua vokal ini mempunyai ciri-ciri pembeza yang berlainan antara satu sama lain. Berdasarkan Jadual 8, vokal / $\mathrm{u} /$ berfitur [+belakang] dan [-depan] manakala vokal /i/ pula berfitur [-belakang] dan [+depan].

Dalam hal ini, fitur [+belakang] dan [-depan] boleh mewakili vokal /u/ dan /o/. Hal ini kerana fitur [+belakang] merujuk kepada vokal belakang dan [-depan] pula bermaksud bukan terdiri daripada vokal depan. Manakala fitur [-belakang] dan [+depan] pula boleh mewakili vokal/i/, /e/ dan /a/. Hal ini kerana fitur [+depan] merujuk kepada vokal depan dan [-belakang] pula bermaksud bukan daripada vokal belakang. Oleh sebab itu, pecahan rumus ini penting kerana setiap vokal masingmasing mempunyai fitur yang berbeza-beza.

Dalam rumus 6, fitur [-tinggi], [-rendah], [+belakang], [-depan] dan [+ATR] yang dinyatakan adalah untuk menyatakan ciri bagi vokal [o] sahaja. Fitur [-tinggi] yang dinyatakan bertujuan mengecualikan ciri vokal/i/ dan vokal/u/, manakala fitur [-rendah] pula bertujuan mengecualikan ciri vokal /a/. Kemudian, fitur [+belakang] yang dinyatakan dalam rumus bertujuan mengecualikan ciri vokal /i/, /e/, /a/ dan /ə/. Fitur [-depan] pula dinyatakan untuk mengecualikan ciri vokal /i/, /e/ dan /a/. Fitur [+ATR] pula dikemukakan untuk mengecualikan ciri vokal /a/. Oleh itu, fitur yang dinyatakan dalam rumus 6 dapat merujuk kepada ciri vokal [o] sahaja.

Menurut Zaharani Ahmad (1993), rumus perendahan vokal yang berlaku telah mengubah vokal tinggi / $u /$ di suku kata akhir tertutup kepada vokal separuh tinggi [o]. Berdasarkan rumus notasi fitur iaitu rumus 6 , vokal /u/ yang berfitur [+tinggi] dan [+belakang] telah kehilangan fitur [+tinggi] apabila ujurannya direalisasikan kepada vokal [o] yang berfitur [-tinggi]. Ciri yang membezakan vokal /u/ dan /o/ ialah fitur [-tinggi]. Menurut Asmah Omar (1995), vokal *u telah menurunkan refleks $\mathrm{o}$, di mana proses yang berlaku merupakan penghilangan ciri [+tinggi] pada $* u$ dan pemasukan ciri [+rendah] yang menimbulkan o. Perubahan

Perubahan Vokal Tinggi di Akhir Kata dalam Dialek Taiping dalam Kalangan Pelajar: Analisis Fonologi Generatif 
kepada o kebanyakan berlaku dalam lingkungan suku kata tertutup dalam kebanyakan dialek seperti perkataan /asuh/ $\rightarrow$ [asoh].

Menurut Teoh (1994), rumus perendahan vokal pada dasarnya merendahkan vokal [+tinggi] kepada vokal [-tinggi] dalam suku kata terakhir untuk membentuk vokal tengah dalam suku kata kedua. Hal ini boleh dilihat dengan mengandaikan struktur asas perkataan ini mempunyai vokal [+tinggi] iaitu Ku\$̧KuK seperti perkataan /pukul/. Namun berdasarkan rumus, vokal [+tinggi] direndahkan kepada vokal [-tinggi] seperti perkataan /pukul/ $\rightarrow$ [pukol]. Berdasarkan struktur KuȘKuK, pada suku kata KuK, vokal /u/ direndahkan kepada [o] (Teoh, 1994). Jelaslah bahawa, analisis sebelum ini boleh dikembangkan secara terperinci. Rumus 2 dikembangkan untuk menunjukkan ciri-ciri fitur vokal [o] itu sahaja, kerana rumus 2 yang dinyatakan Zaharani Ahmad (1993) terlalu umum sifatnya.

\section{Kesimpulan}

Berdasarkan perbincangan, proses perendahan huruf vokal tinggi di akhir kata dalam dialek Taiping mengalami perubahan /i/ kepada [e] dan / $\mathrm{u} /$ kepada [o]. Data yang diperoleh dianalisis menggunakan teori fonologi generatif standard atau model linear akibat pelaksanaan rumus perendahan vokal. Dalam analisis juga, rumus segmen yang dibincangkan oleh pengkaji terdahulu telah dikembangkan kepada rumus-rumus fitur distingtif untuk menjelaskan dengan lebih terperinci tentang proses perendahan vokal yang berlaku.

Hal yang demikian kerana analisis sebelum ini bersifat umum dalam menjelaskan proses perendahan vokal tinggi [i] dan [u]. Hal ini kerana realisasi rumus dalam kajian-kajian sebelum ini turut mewakili huruf vokal [e], [o], [a] dan [ə] kerana semua vokal ini juga merupakan vokal berfitur [-tinggi]. Oleh sebab itu, penilaian semula telah dilakukan dan rumus sebelum ini dikembangkan untuk menjelaskan ciri-ciri vokal itu tersendiri.

Perbincangan vokal tinggi /i/ dan /u/ di akhir kata dilakukan secara berasingan berdasarkan rumus fitur distingtif. Rumus yang dapat menjelaskan perubahan vokal /i/ kepada vokal [e] dikemukakan dalam rumus 4. Setiap fitur yang disenaraikan dalam rumus 4 mewakili ciri-ciri vokal [e] yang mempunyai ciri pembezanya dengan vokal [-tinggi] yang lain. Rumus yang menjelaskan perubahan vokal /u/ kepada vokal [o] pula seperti yang dikemukakan dalam rumus 6 . Setiap fitur yang disenaraikan dalam rumus 6 mewakili ciri-ciri yang terdapat dalam vokal [o] yang mempunyai perbezaan dengan vokal [-tinggi] yang lain.

Dapat disimpulkan bahawa analisis fitur distingtif telah dapat menjawab persoalan bagi perbubahan vokal tinggi /i/ dan / $\mathrm{u} /$ yang berada di akhir kata dalam dialek Taiping kepada vokal [e] dan [o]. Walaupun teori fonologi generatif merupakan teori lama, namun pendekatan tersebut masih relevan digunakan oleh pengkaji baharu yang ingin mendalami bidang fonologi di peringkat awal.

Dari segi dialek Taiping itu sendiri, kajian ini dapat mengetengahkan pengetahuan tentang salah satu dialek yang terdapat di dalam negeri Perak yang belum dibincangkan secara khusus terutama dari segi fonologi. Tambahan pula, sebahagian dialek-dialek di Perak telah pun dikaji sebelum ini seperti dialek Kuala Kangsar, dialek Gopeng, dialek-dialek di Hulu Perak terutama di Gerik, Klian Intan

Perubahan Vokal Tinggi di Akhir Kata dalam Dialek Taiping dalam Kalangan Pelajar: Analisis Fonologi Generatif 
dan Temenggor, selain dialek Rawa. Secara tidak langsung, kajian ini dapat memperlihatkan cara pertuturan dengan menggunakan dialek Taiping, sekali gus menunjukkan perbezaan variasi dialek-dialek yang terdapat di dalam negeri Perak.

Selain itu, kajian ini dapat menunjukkan dialek Taiping masih dituturkan oleh generasi muda, khususnya apabila semua komuniti tersebut berkumpul di lokasi asal yang dapat mengukuhkan jati diri sebagai penutur dialek Taiping sebelum mereka berhijrah ke kawasan lain yang akan mempengaruhi proses asimilasi terhadap dialek Taiping yang asal. Setidak-tidaknya, sebelum mereka berhijrah ke lokasi lain, mereka ada jati diri sebagai penutur dialek Taiping dan tidak melenyapkan dialek itu sendiri. Malah, kajian ini dapat menjadi perintis kepada kajian akan datang yang ingin mengkaji perbezaan pertuturan dialek Taiping antara penutur generasi muda yang cenderung mengalami proses asimilasi dengan bahasa Melayu dan bahasa Inggeris pada masa kini amnya, dengan pertuturan dialek Taiping yang lebih konvensional yang digunakan oleh penutur berumur 50 tahun ke untuk kajian yang berfokus kepada perbezaan sebutan antara generasi yang berbeza-beza.

\section{Rujukan}

Abdul Hamid Mahmood. (2017). Kursus fonetik dan fonologi bahasa melayu untuk pengajian jarak jauh. Tanjong Malim, Malaysia: Persatuan Penulis Budiman.

Abdul Zen Latif. (2016). Perubahan fonologis kosakata serapan sansekerta dalam bahasa jawa. Tesis Sarjana Strata 2. Universitas Diponegoro Semarang, Indonesia. Diperoleh daripada http://eprints.undip.ac.id/48453/1/ABDUL LATIF_ZEN.pdf.

Abdullah Hassan. (2005). Linguistik am. Selangor, Malaysia: PTS Professional Publishing Sdn. Bhd.

Adi Yasran Abdul Aziz. (2012). Fitur distingtif. Retrieved from http://vodppl. upm.edu.my/uploads/docs/Nota\%20Kuliah\%205\%20BBM3202\%20Fitur\%20Di stingtif.pdf.

Adi Yasran Abdul Aziz, Raja Masittah Raja Ariffin, Mohd Sharifudin Yusop, \& Nur Farahkhanna Mohd Rusli. (2014). Pengglotisan geseran /s/ dalam bahasa Kerinci. GEMA Online ${ }^{\circledast}$ Journal of Language Studies, 14(3), 225-242.

Arbak Othman. (1983). Permulaan ilmu linguistik. Kuala Lumpur: Sarjana Enterprise.

Asmah Omar. (1978). Pengajaran bahasa Melayu dalam konteks perancangan bahasa kebangsaan. Kuala Lumpur, Malaysia: Dewan Bahasa dan Pustaka.

Asmah Omar. (1988). Susur galur bahasa Melayu. Kuala Lumpur, Malaysia: Dewan Bahasa dan Pustaka.

Asmah Omar. (1995). Rekonstruksi fonologi bahasa Melayu induk. Kuala Lumpur, Malaysia: Dewan Bahasa dan Pustaka.

Chaiyanara, P. M. (2006). Pengenalan fonetik dan fonologi. Kuala Lumpur, Malaysia: Dewan Bahasa dan Pustaka.

Christiane, A. M. Baltaxe. (1978). Foundations of distinctive feature theory. Baltimore: University Park Press.

Chomsky, N., \& Halle, M. (1968). The sound and pattern of english. New York: Harper \& Row.

Perubahan Vokal Tinggi di Akhir Kata dalam Dialek Taiping dalam Kalangan Pelajar: Analisis Fonologi Generatif 
Farid M. Onn (pnyt). (1988). Bunga rampai fonologi bahasa Melayu. Petaling Jaya, Malaysia: Fajar Bakti.

Harun Mat Piah. (1983, Oktober 20-23). Dialek negeri Perak. Bengkel Kepimpinan dan Pengajian Kebudayaan Negeri Perak, Ipoh, Malaysia.

Indirawati Zahid \& Mardian Shah Omar. (2006). Fonetik dan fonologi. Kuala Lumpur, Malaysia: PTS Profesional Publishing Sdn. Bhd.

Mohamad Shahidan. (2005). Dialek utara semenanjung dalam pantun. Pelita Bahasa November, 44-45.

Nor Hashimah Jalaluddin, Norlisafina Sanit, Zaharani Ahmad \& Harishon Mohd Radzi. (2016). Variasi kata ganti nama dialek di pesisir Sungai Perak: Analisis geographical information system (GIS). Jurnal Bahasa, 16(1), 109-123.

Nur Farahkhanna Mohd Rusli, Adi Yasran Abdul Aziz, Raja Masittah Raja Ariffin, Mohd Sharifudin Yusop \& Saidatul Faiqah Samasu. (2015). Derivasi rumus reduksi vokal dan pembentukan glotis dalam bahasa Kerinci. GEMA Online ${ }^{\circledR}$ Journal of Language Studies, 15(3), 83-97.

Peta daerah negeri Perak. Retrieived from https://belumoutdoor.files.wordpress .com/2010/02/map_perak.jpg.

Roca, I. \& Johnson, W. (1999). A course in phonology. USA: Blackwell Publisher Inc.

Saidatul Faiqah Samasu \& Adi Yasran Abdul Aziz. (2013). Inventori fonem konsonan dialek Melayu Kuching Sarawak. Jurnal linguistik, 17(1), 10-18.

Sakinah Nik Muhammad Naziman \& Fazal Mohamed Mohamed Sultan. (2016). Bentuk dan kedudukan kata tanya Dialek Perak Utara: Satu huraian deskriptif. Jurnal Bahasa, 16(2), 253-274.

Schane, S. A. (1973). Generative phonology. Prentice Halle, Englewood Cliffts, New Jersey.

Shahidi A. H. \& Rahim Aman. (2010). Pengaruh dialek dalam pertuturan bahasa Melayu standard: Pencerakinan bunyi berasaskan spektrogram. Jurnal Bahasa, 10(2), 287-297.

Siti Noraini Hamzah \& Nor Hashimah Jalaluddin. (2018). Kepelbagaian varian leksikal dialek di Perak: Pendekatan geographical information system. Akademika, 88(1), 137-152.

Siti Noraini Hamzah, Nor Hashimah Jalaluddin \& Zaharani Ahmad. (2017). Migrasi masyarakat luar dan pengaruh dialek di Perak: Analisis geolinguistik. Jurnal Bahasa, 17(1), 1-34.

Teoh, B. S.. (1994). The sound system of Malay revisited. Kuala Lumpur, Malaysia: Dewan Bahasa dan Pustaka.

Zaharani Ahmad. (1991a). Fonologi dialek Perak: suatu huraian atur rumus. Dewan Bahasa, 35(6), 484-496.

Zaharani Ahmad. (1991b). Masalah menentukan representasi dalaman dalam kajian fonologi. Dewan Bahasa, 35(12), 1095-1105.

Zaharani Ahmad. (1992). Rumus Transformasi dalam fonologi: penerapannya pada bahasa Melayu. Dewan Bahasa, 36(7), 580-588.

Zaharani Ahmad. (1993). Fonologi generatif: Teori dan penerapan. Kuala Lumpur, Malaysia: Dewan Bahasa dan Pustaka. 